\title{
chapter news
}

\section{Arkansas}

The April meeting took place at the National Weather Service (NWS) office in North Little Rock.

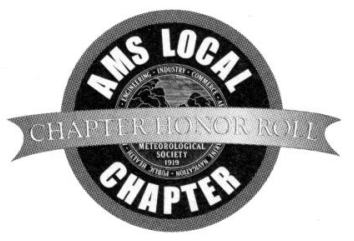

A brief business session took place with Chapter President George Wilken discussing the topics of upcoming meetings and urging the membership to consider presenting a topic of their choice. Chapter member Lawrence Holm volunteered to make a presentation on the Petit Jean Mountain fire, as a follow-up to a previous presentation, for the May meeting. The chapter cookout was announced for June.

The chapter meeting for April featured Sonny Lewis, assistant chief of the Little Rock Air Traffic

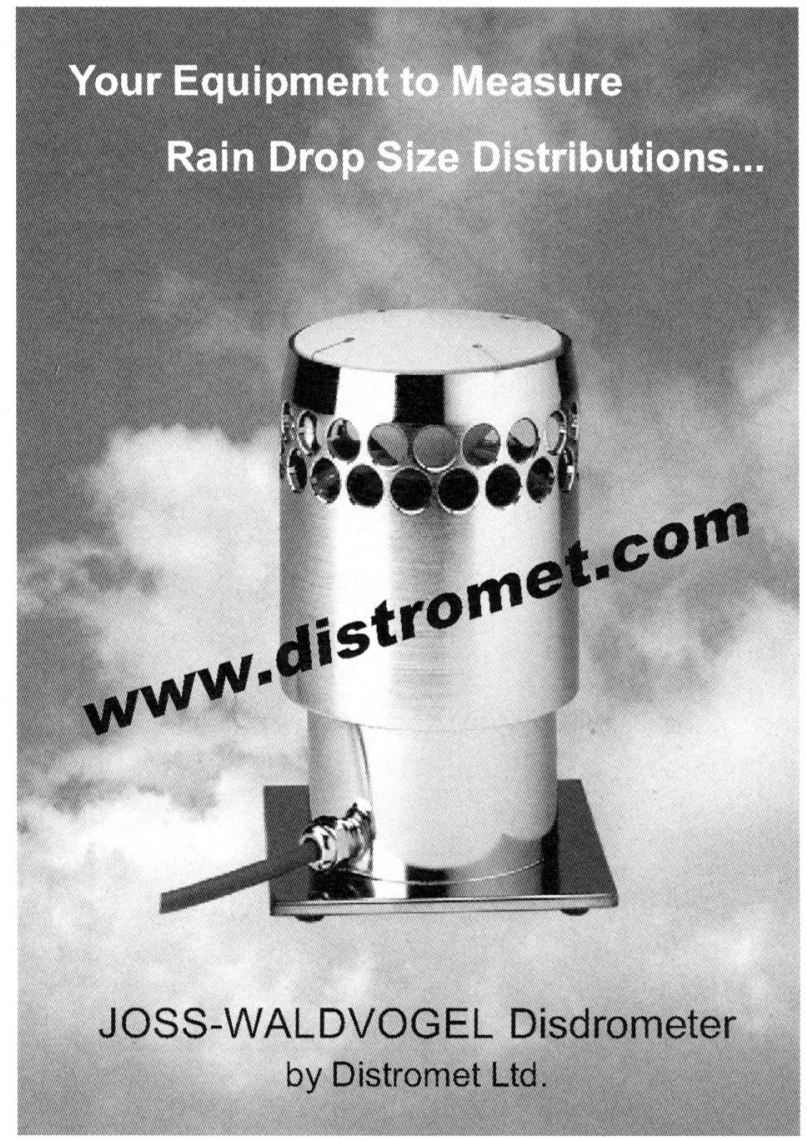

Control Tower. Lewis spoke on the air traffic system in general and addressed what a pilot might be concerned with during flight planning. This provided the membership with some insight into the professionalism of the pilots in commercial aviation. Lewis, previously a commercial pilot, spoke with authority as to what problems pilots have to cope with, both during flight planning and in flight.

The session concluded with the presentation of a video that traced a typical flight across the United States, showing air traffic facility operations from the control tower and air route traffic control center perspectives, as well as what communications take place between the aircraft and each of the facilities.

The May meeting also took place at the NWS office in North Little Rock. A brief business session took place with Wilken discussing the possible topics for the fall meetings.

The program for the evening was presented by chapter member Lawrence Holm, fire weather analyst and dispatcher for the Arkansas Forestry Commission. Holm talked about fuels in the forests and the effect weather conditions have on the fuels. He described how fires in the forests behave under specific conditions. Fire suppression limitations were discussed and Holm described how fires react in different topographic areas.

He also showed a U.S. Forest Service video called, "On The Fire Line." The video described Forest Service operations during wildfires, and how proper management of forests can reduce wildfires.

The June meeting was the annual chapter cookout. Wilken mentioned that he was retiring from the NWS in late August, but that his activity with the chapter will remain unchanged. It was also mentioned that one prospect for a fall meeting would be a local radio personality who is interested in weather.

Active weather was in the area, and attendees were also serenaded by a passing thunderstorm or two.Newton Skiles

\section{Cook College-Rutgers University}

On 7 April the chapter visited the NBC-10 studio 
in Philadelphia, Pennsylvania. The on-camera meteorologist allowed members to attend one of the live tapings of the news. After the taping, the meteorologist gave a tour of the studio and let members try some of the equipment, such as the green and blue screens.

On 27 April, Paul Kocin, the winter weather expert at The Weather Channel, came to Cook College at Rutgers University to give a talk. He spoke on what his job involves during the winter season as well as the other seasons, his upcoming book, and the past 2000-01 winter season. He also showed a bloopers tape of The Weather Channel.

The 1 May meeting featured discussions on upcoming events in the new school year. One possibility was getting certified by Skywarn as a group. The chapter also discussed the idea of working at Great Adventure as a fundraiser. By helping out at Great Adventure, the park would give the chapter a certain amount of money in return. The chapter also plans to have a fundraiser around Halloween by selling pumpkins to students. The idea of donating toys to a charity such as Toys for Tots around Christmas was also brought up.

The 8 May meeting featured plans for student advising, meteorology club/faculty Christmas party, and a senior farewell/new board member ceremony. For the student advising, the older members of the club would be assigned an incoming freshman buddy. The job of the older members would be to help the freshman with scheduling, picking relevant classes, and any other questions or concerns they have. This has already gotten underway for the fall, and letters were to be sent out to the prospective freshman. Plans for a Christmas Party for the club members, meteorology majors, and faculty were also put together. The last plan discussed was the farewell/new board for the meteorology club. For this, an end-of-the-year barbecue was planned. At the barbecue, the old executive board would give their goodbye speeches and then elections would be held. The seniors on the board would hand over their positions to the new board and explain the jobs involved with each position. This was last gathering of the club for the year.-Lisa M. Robak

\section{Central North Carolina}

The chapter's annual year-end banquet was held 4 May at The Brownestone Hotel in Raleigh with approximately 50 members and guests attending.

After dinner, Chapter Vice-Chairman Joel Cline welcomed everyone and gave a few words of introduction. Outgoing Chairman John White looked back at the past year, noting an increase in chapter member- ship, thanking the current year's officers and Emily Byrd for helping to organize the banquet. Cline then recognized each of the speakers from chapter meeting throughout the year: Chris Coudriet (September), Grant Goodge (October), Len Pietrafesa (November), Orrin Pilkey (December), Jay Barnes (January), Roscoe Braham and Walter Saucier (February), WRAL-TV (March), and Walter Bach (April). Each speaker was presented with an AMS mug as a sign of the chapter's appreciation.

Al Riordan, chairman of the education committee, then presented the annual chapter scholarship awards to four graduating students: Robbie Berg, North Carolina State University; Scott Parker, North Carolina State University; Tim O'Connor, Duke University; and Chun-Ta Lai, Duke University.

Next, Cline introduced Ron McPherson, executive director of AMS, and his talk, "What's New at the AMS?" McPherson outlined the 10-Year Vision for the Society that included four main themes: 1) an emphasis on multidisciplinarity, 2) greater inclusiveness, 3 ) aggressive outreach to the public and decision

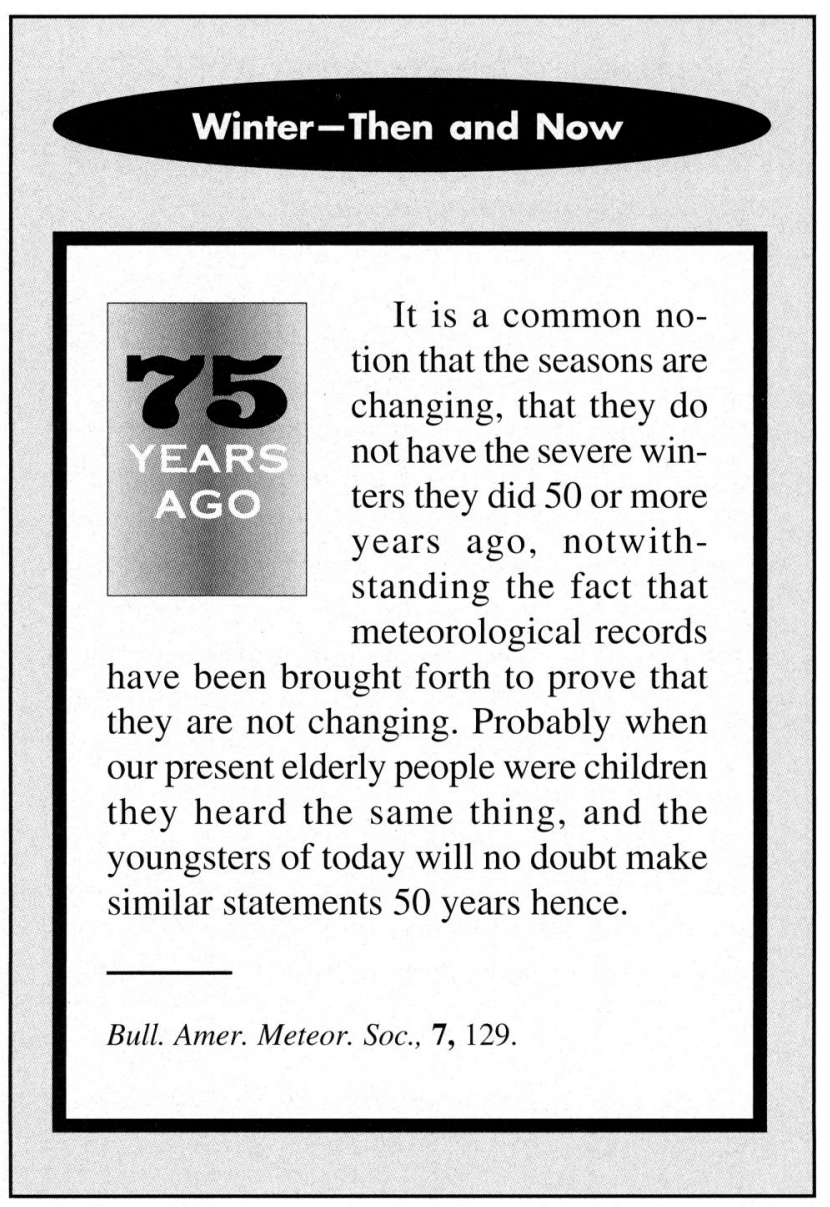


makers, and 4) maximizing the use of technology. He began by outlining new features in the realm of AMS publications, beginning with the news of a new AMS Bulletin. News with other publications includes nine current journals, one that is published only online. The other eight are also available online. One area of improvement the AMS is striving for is shortening the journal production time, reducing the time from when the manuscript is received in final form until publication to 150 days from the current average of 210 days.

Other current activities at the AMS involved a new public information officer and expansion of the

\section{Announcing the "Compendium of Meteorology," edited by Thomas F. Malone}

Published by the AMS, this large work has been made possible through support and sponsorship extended by the Geophysics Research Division of the Air Force Cambridge Research Center.

Preparation of three years has been involved in the writing, editing, and publication arrangements for the Compendium of Meteorology. This is easily understood when one views the scope of the book, 102 interna-

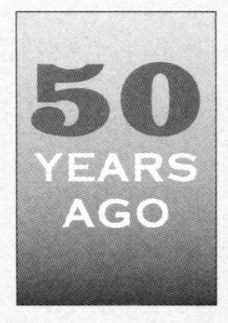
tionally represented authors, 108 articles on topics of weather from pole to equator, from microseisms to the ionosphere. The purpose of the Compendium is to summarize and appraise what is known of meteorology and to point the way toward further progress. Meteorologists and atmospheric physicists have combined their efforts in fulfilling this purpose.

$[\ldots]$ Never before has such an extraordinary task been undertaken in the history of meteorology. This work, which we believe will attain the position of a classic, reveals clearly at mid-century the challenge which faces those most concerned with the atmosphere and its phenomena.

Bull. Amer. Meteor. Soc., 32, 294.
Society's public information program. One example was the preparation of a transition document on natural hazards for the new presidential administration. McPherson encouraged all AMS members to write their respective senators and representatives to urge them to support increased investment in the physical sciences, budgets for the federal agencies with atmospheric programs (NOAA, NASA, DOE, DOD, EPA), and the U.S. Weather Research Program. Finally, McPherson outlined areas where he felt the Society needs to improve its efforts: attracting the brightest students, reaching more science teachers, promoting science literacy, exposing students to policy issues, promoting the profession, and preserving the history of the science.

Next, John White introduced the newly elected officers for 2001-02: Chapter Chairman Frank Schiermeier, Chapter Vice-Chair Emily Byrd, Chapter Secretary Michael Brennan, and Chapter Treasurer Shaun Baines.

Finally, to close the evening, Schiermeier asked each member to help increase chapter membership by encouraging a friend or colleague to join next year.Michael Brennan

\section{Greater Miami}

The last meeting before the beginning of the hurricane season was held on 30 May at the Tropical Prediction Center/National Hurricane Center in Miami. The newly elected Chapter President, Jason Dunion, called the meeting to order. After chapter business was discussed, V. Mohan Karyampudi from NOAA/NCEP was introduced as the guest speaker. His talk was titled "Influence of the Saharan Air Layer on Tropical Cyclogenesis over the North Atlantic."

In the presentation, Karyampudi said that although it is well known that African waves are the seedlings for a majority of tropical storms that form over the North Atlantic, tropical cyclogenesis in this region remains an enigma. In order to address this issue, Karyampudi and Pierce (WHO IS PIERCE?-ASK KELLY) have recently conducted a detailed study using four cases that consecutively occurred during the 1992-95 hurricane seasons. Based on these results, they suggested that tropical cyclogenesis over the eastern Atlantic is largely influenced by the Saharan Air Layer (SAL), which is frequently transported by the African waves across the Atlantic (Carlson and Prospero 1972). In particular, they have shown that the sign reversal of the meridional gradient of potential vorticity (PV) exists across the mid-tropospheric jet 
located to the south of the SAL, which satisfies the Charney and Stern (1962) criterion for barotropic and baroclinic instability [first applied by Burpee (1972) to explain the growth of African easterly waves over North Africa]. Furthermore, Karyampudi and Pierce have deduced from vorticity budget analyses that vortex merger at the synoptic-scale dominates the genesis process, in which PV advection on the southern leading edge of the mid-level jet contributes to the growth of the midtropospheric disturbance, whereas vortex stretching dominates the enhancement of low-level vortices. These results were discussed in the context of explaining the likely origins of tropical storms that occurred over the tropical Atlantic in the 2000 hurricane season, including the uncertainties in the identification of the SAL in large-scale datasets such as the operational global model data.

The 11th Annual Miami-Dade County Elementary Science and Mathematics Fair was held on 24 May at the Dade County Public Schools Administration Building in Miami. Three chapter members served as science judges for the event: Shirley Murillo, Laura Salvador, and Arturo Rodriguez.

The first-place winner was Katherine Fiallo, a second grade student from the Miami Satellite Learning Center. Her project's title was "Which Temperature Forecast is Most Accurate?" In the project, Fiallo compared forecasts made by different local television meteorologists (at different time slots) of daily high and low temperatures to those made by the NWS.

An honorable mention was awarded to Jennifer Martinez, a second-grade student from Maya Angelou Elementary School. Her project was titled "Hot Stuff .. . What is the Hottest Hour of the School Day?" Martinez measured the air temperature outside her classroom for several days and noted that the hottest temperature is reached at about 3:30 P.M. on a typical day in Miami._Jason Dunion

\section{Twin Cities}

The chapter ended the 2000-01 year with a field trip to DTN/Kavouras and a barbecue at Lake Susan. Jim

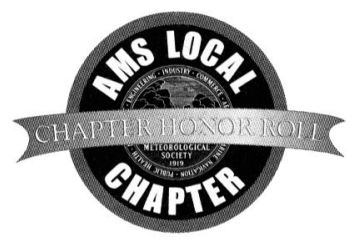
Block of DTN/Kavouras provided a brief history and introduction of the types of services that DTN (Data Transmission Network) provides. DTN originally started as a satellite information provider but has expanded its services over the years to include agricultural- and commodity-based services, DTNergy services, and DTNstant financial services as well.
Currently, DTN/Kavouras has been bought by Veronis Suhler and will be known as Meteorologix in the future. Meteorologix will expand its services to government and aviation (airlines, FAA), commercial interests (agriculture, utilities), and the media (broadcast television/radio, Internet) with an emphasis on providing "weather specific" business solutions.

Doug Chenevert, director of Workstation Software Development at DTN/Kavouras outlined two new software products to be implemented for use by the broadcast media: Metrocast was funded by American airlines and is based on ARRPS.

Chenevert said Metrocast will assimilate radiosonde, aircraft, radar, satellite, and NEXRAD information. This model can be run each hour and will output data on precipitation (RA,SN,PE), stability (CAPE, LI, helicity), surface visibility, cloud cover, icing, and turbulence. Metrocast has a Web-based interface that will allow remote access via the Web.

Chenevert explained that Dopplercast is a forecast radar reflectivity model based on MIT reflectivity algorithms. This model was developed at NSSL and utilizes NEXRAD composite reflectivity to forecast base reflectivity. Dopplercast filters mesoscale and

\section{STOP RECURRING DATA FEES!}

Fast access to NOAA products via satellite

Receive free data from NOAAPort

GOES imagery

Model data

Observations

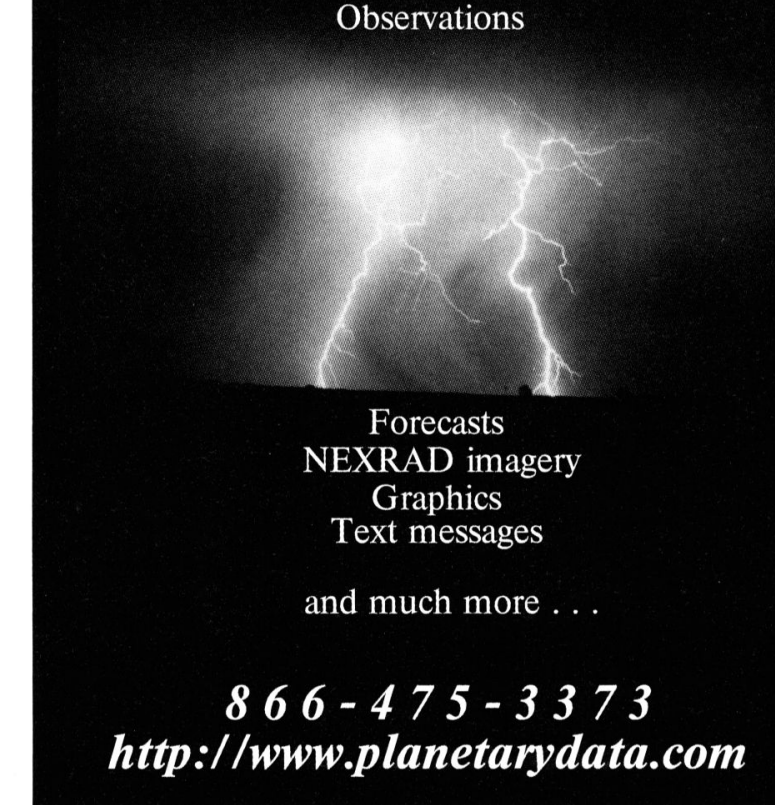


stormscale motion components and evaluates all growth and decay of storm cells. Dopplercast will forecast reflectivity at five-minute time steps out to 60 minutes. Chenevert said that Dopplercast is currently being used operationally at FAA control centers.

The chapter concluded its year with a barbecue at Lake Susan in Chanhassen. Brian Connelly, a hydrologic forecaster at the NWS North Central River Forecast Center in Chanhassen, Minnesota, spoke on "2001 Spring Flooding in Minnesota and the Upper Mississippi River Watersheds." Connelly presented a colorful handout illustrating both the November 2000 and April 2001 departure from normal precipitation that influenced this years flooding in Minnesota. He also presented a flood stage report that summarized "above flood stage" data for 20 river stations along the upper Mississippi River. The presentation ended with a discussion on the future improvements in hydrologic forecasting.-Mary Beth Howard

\section{Central Illinois}

The 20 June meeting was held at Mavericks Steakhouse in Decatur, Illinois. Members attended from the Springfield, Lincoln, Bloomington-Normal,

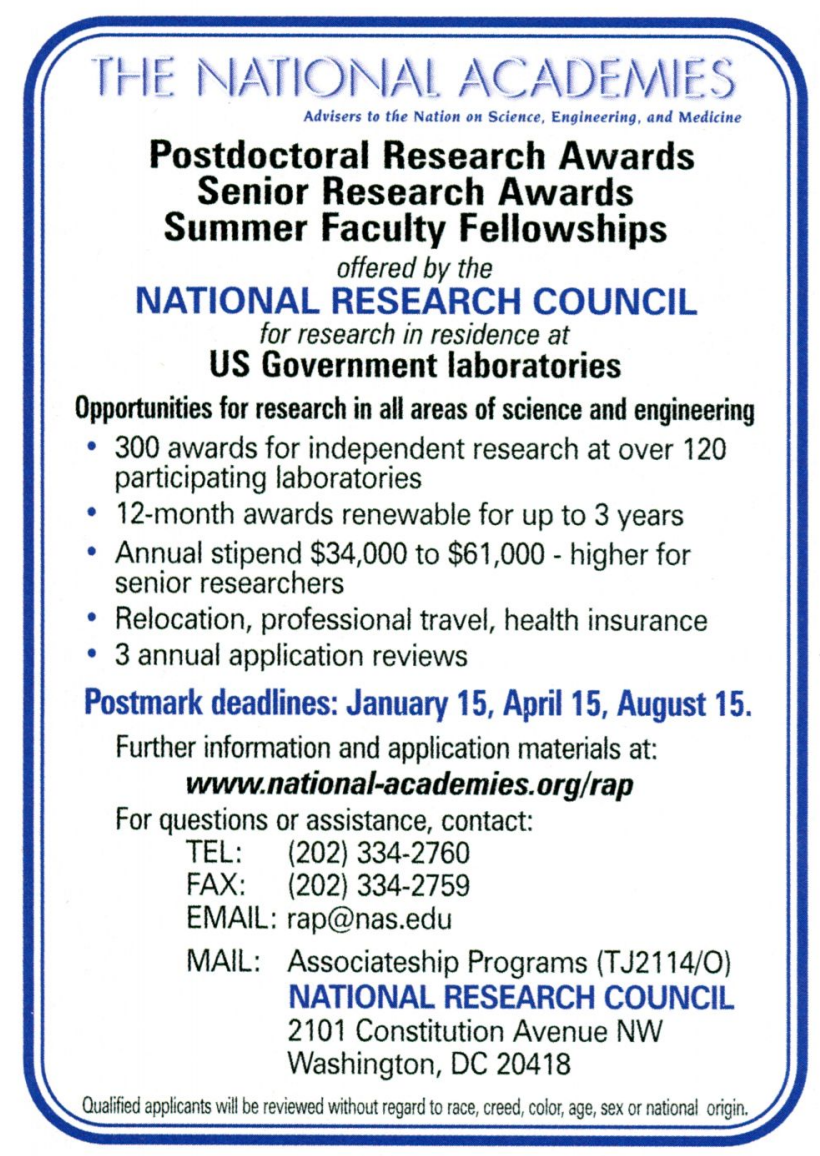

and Champaign-Urbana areas. After dinner, Chapter President Rod Palmer called the meeting to order. Palmer made a motion to amend the bylaws to combine the publicity committee with the program committee and the nomination committee with the membership committee. The motion passed unanimously. The chapter now has the following committees and committee members: Education Committee, Walter Robinson-Chair, James Carter, and Julie Bauer; Membership and Nominating Committee, Ed Holicky - Chair, Rod Palmer, Melissa Davis, and John Parr; and Program and Publicity Committee, David Kristovich - Chair, Ed Holicky, and Chris Miller.

Chapter Vice President Ed Holicky then spoke about participation in the Illinois Science Olympiad. He also spoke about creating a new scholarship/savings bond to be awarded annually to a junior or senior in high school or a freshman or sophomore in college. The plan is to award $\$ 500$ a year starting with the August meeting. The Education Committee will decide on the recipient.

The speakers for the meeting were Bob Swinford and Rob Kaleel of the Illinois Environmental Protection Agency (IEPA). Swinford works for the IEPA Bureau of Air-Air Monitoring Section, which monitors and reports the air quality of the ambient air across Illinois. In his presentation "Air Quality Trends in Illinois" it was stated that the IEPA measures maximum concentration, population exposure, source-oriented, and background sampling. Criteria pollutants monitored are ozone $\left(\mathrm{O}_{3}\right)$, particular matter (PM $10 \mu \mathrm{m}$ and PM $2.5 \mu \mathrm{m})$, sulfur dioxide $\left(\mathrm{SO}_{2}\right)$, carbon monoxide $(\mathrm{CO})$, nitrogen dioxide $\left(\mathrm{NO}_{2}\right)$, and lead $(\mathrm{Pb})$.

Swinford said that air quality trends in Illinois over the last 25 years show that the concentrations of $\mathrm{Pb}$, $\mathrm{CO}, \mathrm{SO}_{2}$, and $\mathrm{NO}_{2}$ have fallen since the late 1970s. Ozone $\left(\mathrm{O}_{3}\right)$ has shown a slight downward trend, with the exception of "spikes" in 1983, 1987, 1988, and 1995 due, in part, to adverse meteorological conditions. In Illinois, the highest concentrations of ozone are usually found in the Chicago area and the Metro East of St. Louis, although higher than desired concentrations are sometimes found in central Illinois. Swinford said that the highest concentrations of ozone are typically found during the summer months, especially during afternoon hours.

The trend for particulate matter (PM) is down during the past 25 years, but standards have changed. Swinford said the PM standard is now $2.5 \mu \mathrm{m}$ compared to older standard of $10 \mu \mathrm{m}$. The highest concentrations of PM in Illinois are also found in the Chicago 


\section{Total Ozone Column Measurements \& UV-B Accurate Ozone and Solar Irradiance with Handheld Meter, Long Term Stability for Erythemogenic UV}

Microtops II, a handheld 5-filter channel sunphotometer, is a breakthrough in Total Ozone Measurements! An inexpensive portable ozonemeter with the accuracy of Dobson and Brewer spectrometers. Real time, on-board data processing, stores raw and processed data, displaying ozone, water vapor, AOT and spectral intensity. Fast scanning permits measurements from moving platforms.

The 501 UV-Biometer, follows the CIE erythemogenic action spectrum more closely than any commercial meter. Stability change $<2 \%$ annually. Field life exceeds 30 years, based on classic R-B meter built by same designers. In use by over a dozen National Laboratories and Meteorological Services, in over 25 countries.
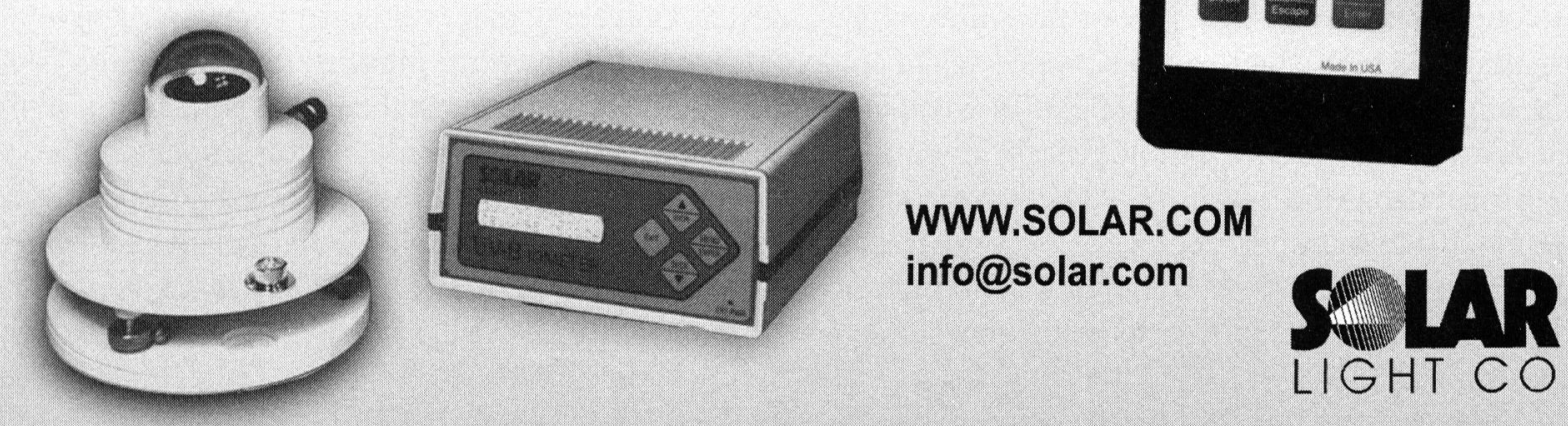

721 OAK LANE PHILADELPHIA, PA 19126. USA

TEL: 2159274206 FAX: 2159276347

area and Metro East of St. Louis. The measure of PM 2.5 composition includes carbon (organic and elemental), sulfate, nitrate, ammonia, and crustal material.

Rob Kaleel of the IEPA's Air Quality Planning and Model Unit then spoke on "Air Quality Modeling at IEPA." His unit does modeling on ozone and fine particulates. He described the Urban Airshed Model (UAM) modeling system. Inputs into the UAM include meteorological conditions and forecasts, emissions, and air quality. It is a gridpoint model with a resolution of $4 \mathrm{~km}$ and $6 \mathrm{~min}$, and contains 7 to $9 \mathrm{lev}-$ els. For central Illinois, higher concentrations of ozone originate from the St. Louis area, although ozone sometimes travels from the Gulf Coast and Southeast states.

Kaleel said that the IEPA is also working with the U.S. EPA on a regional haze program. Haze is mostly a summer problem. Some closely monitored areas include the Shenandoah Valley of Virginia and in the Boundary Waters Canoe Area of Minnesota. It is hoped that reductions in visibility can be improved in coming decades.
In the previous meeting in Lincoln, Illinois, the speaker was Donald Wuebbles, department head and professor of atmospheric sciences at the University of Illinois. He spoke on "Achieving a Sustainable Climate." Wuebbles said that there is evidence of global warming, citing seven of the last 11 years featuring the highest global average temperature (of the last 150 years). Some evidence includes a major decline in glacier extent, an increase in water vapor in the air, increasing cloud cover compared to 1950 s, increased precipitation in high latitudes, a shortened lake ice season, and less snow cover. He said other findings indicate that the stratosphere is cooling and the diurnal range of temperature is decreasing.

Wuebbles pointed out that various climate models offer various solutions, but all indicate an increase in the global average temperature for the 100-year period from 1990 to 2090 of $2^{\circ} \mathrm{F}$ to $11^{\circ} \mathrm{F}$. Wuebbles spoke on various scenarios based on climate models. Some concerns include changes in temperature, precipitation, winds, sea level, and severe weather.-Ed Kieser 